\title{
OVERVIEW OF ITMK3 PROCESS
}

\author{
Abhilasha Gulhane \\ IIT Kharagpur, West Bengal, India
}

\begin{abstract}
This paper presents the overview of the ITmk3 process, which is low cost process that produce iron-nuggets without lump-ore. This direct-reduction iron-making process suffers much less from the restriction of raw materials and is superior in energy efficiency. It is getting more attention due to the growing concerns about the conservation of resources and environment. This process is about to be used commercially.
\end{abstract}

Keywords: Alternative methods of iron making, DRI, Ironmaking, ITmk3, Steelmaking.

Cite this Article: Abhilasha Gulhane, Overview of ITmk3 Process, International Journal of Industrial Engineering Research and Development, 8(2), 2017, pp. 1-4. https://iaeme.com/Home/issue/IJIERD?Volume=8\&Issue=2

\section{INTRODUCTION}

Coal based direct reduction processes are the alternative ways of iron and steel making. The necessity of the new processes are due to expensive coke, abundant availability of the fine ore and large energy consumption in blast furnace process causing a high burden on the environment. Kobe Steel, along with MIDREX Technologies has developed a coal based DR process which utilizes non-coking coal as a reductant instead of natural gas and is expanding the market share in the coal-based iron-making field. FASTMET, FASTMELT and ITmk3 are low cost processes that produce directly reduced iron (DRI) without coke, hot-metal without fired- pellets and iron-nuggets without lump-ore, respectively.

ITmk3 is the third main breakthrough in ironmaking. The ITmk3 separates nugget iron and slag directly from the iron ore fines and pulverized coal. ITmk3 is considered to be the 3rd generation ironmaking process, and the current mainstream process of blastfurnace/converter as the 1st generation and the direct reduction process such as MIDREX is the 2 nd generation. The process is based on a totally different concept from the conventional processes.

\section{ITMK3 PROCESS}

\subsection{Development History}

ITmk $3{ }^{\circledR}$ process is evolved from the FASTMET ${ }^{\circledR}$ Process. Both FASTMET and ITmk3 use an RHF to reduce pellets or briquettes made from iron oxide fines and coal. The hearth is essentially a large turntable that rotates within a toroidal enclosure. The feed pellets (composite agglomerates made from iron oxide fines and a carbon source such as coal, 
charcoal, or other carbon-bearing materials) are charged to the hearth, one to two layers deep, and as they move on the hearth, they are heated by burners firing above the hearth and combustion of gases liberated from the pellets. One revolution of the hearth takes approximately ten minutes. In FASTMET ${ }^{\circledR}$, the product is direct reduced iron, but in ITmk $3^{\circledR}$, the pellets are melted in the last zone of the hearth to produce a premium quality pig iron product with a slag by-product. Plants can be located at mine sites or in steelmaking facilities. ITmk $3{ }^{\circledR}$ enables mining companies to produce a value-added product and steelmakers to obtain a premium quality feedstock for EAF or BOF use. Plants are under construction and development worldwide. Blast furnace processes limits the types of resources, such as raw materials, that can be used.

Steel Dynamics, Inc. and Kobe Steel constructed first commercial plant with a capacity of 500 thousand tonnes/year of granular iron. The construction of the commercial plant began in June 2007, and production started in 2010. The construction of another commercial plant in Michigan, in the U.S., is being planned in collaboration with Cleveland-Cliffs Inc. Commercial plants are also being planned in many other countries, including Kazakhstan, India and Ukraine.

\subsection{Process and Product}

The following reactions proceed when the carbon composite pellet is heated to 1,350 to $1,450^{\circ} \mathrm{C}$.

$$
\begin{aligned}
& \mathrm{Fe}_{\mathrm{x}} \mathrm{O}_{\mathrm{y}}+\mathrm{yCO}=\mathrm{xFe}+\mathrm{yCO}_{2} \\
& \mathrm{CO}_{2}+\mathrm{C}=2 \mathrm{CO} \\
& \mathrm{C}(\mathrm{s})=\mathrm{C}(\text { carburized }) \\
& \mathrm{Fe}(\mathrm{s})=\mathrm{Fe}(1) \text { (molten) }
\end{aligned}
$$

The series reactions complete in approx. $10 \mathrm{~min}$ and separate iron and slag completely. The specific consumption figures per ton of nuggets for the ITmk 3 process are as follows:

ITmk3 produces slag free Iron nuggets which have similar chemical and physical properties to those of pig iron. It has a metallic iron content of $96-97 \%, \mathrm{C}$ content of $2.0-2.5$ $\%$. Sulphur levels in the nuggets are around $0.07-0.11 \%$. The density of iron nuggets is in the range of 6.5-7.0 gm/CC. Iron nuggets have better meltability than blast furnace pig iron since it has a low melting point and higher thermal conductivity. Iron nuggets are having size which helps in easy transportation and handling. They do not reoxidize and also do not generate fines during handling. Another advantageous feature of the iron nuggets are that they can be continuously charged into the Electric Arc Furnace similar to DRI/HBI.

Table 1 Chemical analysis of iron nuggets

\begin{tabular}{|c|c|}
\hline Item & Content (\%) \\
\hline Metallic Fe & 97.0 \\
\hline $\mathrm{C}$ & $2.0-2.5$ \\
\hline $\mathrm{P}$ & $0.01-0.02$ \\
\hline $\mathrm{S}$ & $0.07-0.11$ \\
\hline
\end{tabular}




\subsection{Advantages of ITmk3 Process}

The process is simple and consumes approximately $30 \%$ less energy than BF. It allows direct reduction of iron ore fines with non coking coals. It eliminates sinter/pellets plant and coke oven battery. The process produces high-grade iron nuggets with better meltability than pig iron during the steel making stage. The iron nuggets are slag free and are also free from re oxidation. It does not generate fines and is easy to transport. Nuggets are also free from tramp elements. The process eliminates necessity of handling molten iron. Operation and adjustment of the process is simple. The process also facilitates the production adjustment by starting and stopping.

Table 2 Specific Consumption values for ITmk 3 process

\begin{tabular}{|l|c|}
\hline \multicolumn{1}{|c|}{ Iron ore fines } & $\mathbf{1 . 5}$ tons \\
\hline Non coking coal & $0.5 \mathrm{ton}$ \\
\hline Fuel gas & $4.6 \mathrm{GJ}$ \\
\hline Electric power & $200 \mathrm{kWh}$ \\
\hline Water & $2 \mathrm{~m}^{3}$ \\
\hline Air & $85 \mathrm{~m}^{3}$ \\
\hline Nitrogen & $12 \mathrm{~m}^{3}$ \\
\hline
\end{tabular}

The granular iron produced by the large pilot plant are received by large EAF based steel makers in the U.S. and are used as a raw material for their steel products, such as sheet, plate. Use of granular iron improves the productivity and energy efficiency of the EAF based steelmaking process. The manufacturers can secure the source for clean iron. It allows conversion to higher end steel products. Installing granular ironmaking plants in steel mills allows the use of hot granular iron, which further increases energy efficiency. ITmk3/EAF steel making produces lesser pollutants relative to Coke/BF/ BOF route.

Table 3

\begin{tabular}{|c|c|}
\hline Pollutant & Reduction (\%) \\
\hline $\mathrm{CO}$ & 96.0 \\
\hline $\mathrm{NOX}$ & 65.0 \\
\hline $\mathrm{SO}_{2}$ & 77.7 \\
\hline $\mathrm{VOC}$ & 86.5 \\
\hline $\mathrm{CO}_{2}$ & 41.1 \\
\hline $\mathrm{Hg}$ & 58.0 \\
\hline
\end{tabular}

The new process does not require equipment with a high environmental load, such as coke ovens and sinter plants. It allows the use of low grade materials. Ironmaking by this process requires a small capital investment and facilitates production adjustment. Granular iron production overseas enables the offsetting of $\mathrm{CO}_{2}$. Granular iron decreases the cost and $\mathrm{CO}_{2}$ emissions associated with transportation, compared with iron ore and pellets. Granular iron generates less slag than do iron ore and pellets. 


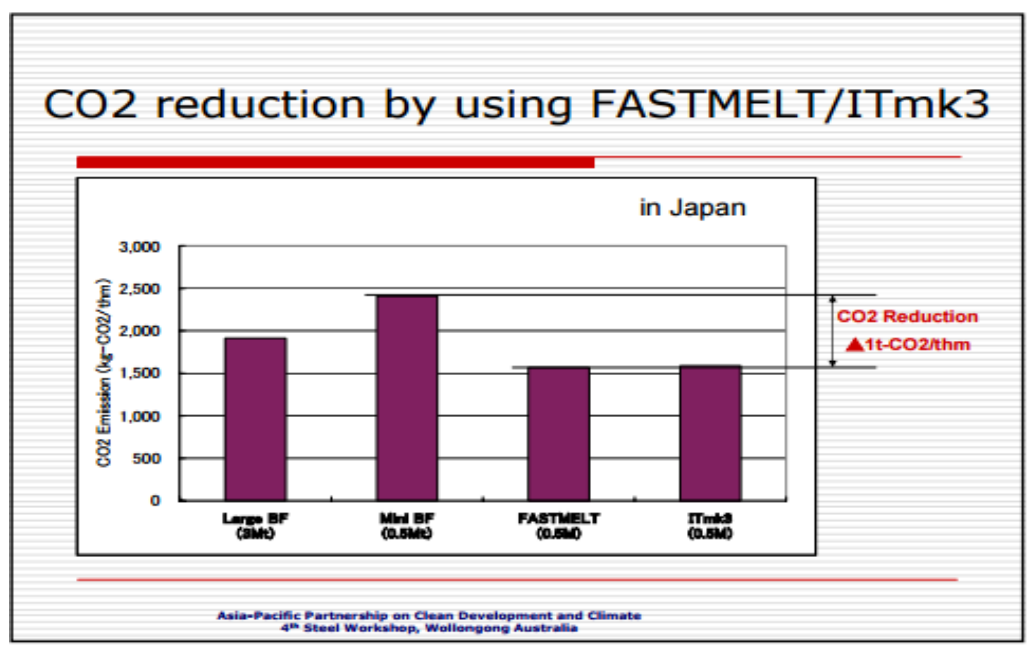

\section{CONCLUSIONS}

The increasing emphasis on the environment creates a need for such innovative and efficient solutions which also reduce carbon emissions from iron. ITmk $3{ }^{\circledR}$ is an ideal way for iron ore mining companies to process either magnetite or hematite and supply a premium quality pig iron product to the steelmaking industry. Moreover, the ITmk3 Process can use cheaper lowgrade iron ore and coal, which are difficult to use in blast furnace ironmaking, to keep raw material costs down for steel and mining companies. Along with these advantages, the real value of the ITmk3 Process is that it produces high-grade iron nuggets with better melting characteristics than blast-furnace pig iron when used in the steelmaking stage.

\section{REFERENCES}

[1] Larry Lehtinen: Mesabi Nugget Research Project, United States Department of Energy (2005).

[2] S. Meissner et al.: The 11th Japan-Germany Seminar on Fundamentals of Iron and Steelmaking, Reduction and Meltdown of Pellets in the ITmk3 Process, (2002).

[3] T. Harada, et al., R\&D Kobe Steel Engineering Reports, Vol. 51, No 2, p. 23 (2001).

[4] H. Tanaka, et al., R\&D Kobe Steel Engineering Reports, Vol. 52, No 3, p. 113 (2002).

[5] http://www.kobelco.co.jp/english/ktr/pdf/ktr_29/077-084.pdf

[6] http://www.kobelco.co.jp/english/ktr/pdf/ktr_26/092-097.pdf

[7] http://ispatguru.com/itmk-3-process-of-making-iron-nuggets/

[8] http://www.asiapacificpartnership.org/pdf/Steel/3rd_meeting/The\%20Kobe\%20Midrex\%2 OProcess.pdf

[9] http://www.steeltimesint.com/news/view/next-generation-itmk3-process-starts-producinghigh-purity-iron-nugget

[10] Rahul Davis, Mohamed Alazhari, Analysis and Optimization of Surface Roughness in Dry Turning Operation of Mild Steel, International Journal of Industrial Engineering Research and Development (IJIERD), 3(2), 2012, pp. 01-09

[11] Dr. B.V.R. Ravi Kumar, A Review on Importance of Microalloying in Steel. International Journal of Industrial Engineering Research and Development (IJIERD), 5(2), 2014, pp. $187-193$ 